James Windle. (2013). 'A Very Gradual Suppression: A History of Turkish Opium Controls, 1933-1974'. European Journal of Criminology. Pre-print copy.

\title{
A VERY GRADUAL SUPPRESSION: A HISTORY OF TURKISH OPIUM CONTROLS, 1933-1974
}

\begin{abstract}
Before 1974 controls over Turkey's opium production were ineffective and provided opportunities for large-scale diversion, making it one of the world's largest sources of illicit opium. The state monopoly was limited by a lack of authority over opium producing areas, laissez faire controls and poor state procurement practices. Policies administered between 1933 and 1971 did, however, represent a period of organisational learning which led to the establishment of a highly successful drug control policy. A secondary finding of this paper, revealed whilst analysing diversion estimates, suggests that there may be inaccuracies in assumptions of geographical displacement from Turkey. While these assumptions have been reproduced in much of the literature, the data suggests that the Turkish opium ban of 1971 had either minimal impact on global, or regional production levels, or that displacement occurred during the 1960s rather than the mid-1970.
\end{abstract}


James Windle. (2013). 'A Very Gradual Suppression: A History of Turkish Opium Controls, 1933-1974'. European Journal of Criminology. Pre-print copy.

\section{A VERY GRADUAL SUPPRESSION: A HISTORY OF TURKISH OPIUM CONTROLS, 1933-1974}

Until 1971 Turkey was one of the world's largest sources of illicit opium. A small number of studies have investigated the original 1971 Turkish opium ban (Murphy and Steele 1971; Robins 2007; Spain 1975; West 1992) and the control of licit opium poppy cultivation administered after 1974 (Mansfield, 2001; Windle, under consideration). Little attention has, however, been given to opium control policies administered by Turkey between 1933 and 1971. This article reconsiders post1974 Turkish opium controls as the latter end of a period of gradual policy improvement.

While pre-1971 policies were largely ineffective, they offer important lessons for contemporary counter-narcotic strategies. They highlight the importance of, not only maintaining state control over opium producing areas, but also the ineffectiveness of state controls over licit production centred upon laissez faire controls and poor state procurement practices. These policies were not, however, in vain. They were part of a period of organisational learning whereby principle actors in Turkish state institutions changed their policies in response to information and experiences about the effectiveness of controls over opium production. This led to the establishment of a highly successful control policy.

A secondary finding of this paper, revealed whilst analysing diversion ${ }^{1}$ estimates reported during the 1960s and early-1970s, is that there may be inaccuracies in established assumptions about geographical displacement from Turkey. It is suggested that the Turkish opium ban of 1971 had either minimal impact on global or regional production levels, or that displacement occurred during the 1960s rather than the mid-1970.

This paper begins with an introduction to organisational learning theory before presenting a brief history of opium production and trade in Turkey. This is followed by a discussion on how successive Turkish governments administered gradually more effective controls over opium cultivation and production. While gaps exist in our knowledge of how pre-1971 controls were enforced, this article goes some way towards rectifying a blind-spot in the history of international drug policy. 
James Windle. (2013). 'A Very Gradual Suppression: A History of Turkish Opium Controls, 1933-1974'. European Journal of Criminology. Pre-print copy.

\section{Organisational learning}

Levitte and March (1988; also Kenney 2009) have defined organisational learning as the process by which an organisations routines and practices change as a result of past experiences. Individuals gain experiences through doing their job. These experiences incrementally add to an organisations collective memory (Kenney, 2009). While direct experience is often the 'most relevant form of knowledge' (Zarkin 2010: 31) organisational change can also be brought about by drawing on the experiences of external agencies, research reports, policy assessments and interaction with experts (Levitte and March 1988; Zarkin 2010). The collective memory is created by the formal (i.e. rules, documents, laws, procedures, training) and informal (i.e. cultures, stories) recording of experiences (Levitte and March 1988).

Learning is often motivated by problems (Schultz 2005). If flaws are identified in policies then individuals design new policies by drawing upon the collective memories of the institution and/or external agencies. During this process individuals debate and negotiate different experiences, and the ideas they establish (Zarkin 2010).

What is witnessed in the present case study is a slow adaption of an entrenched policy in which state employees and external actors identified weaknesses and strengths until reaching a tipping point in the early-1970s, whereby external agencies demanded radical change. At this point Turkey was able to access accumulated knowledge to develop an effective policy. That the intervention was a gradual process is not unusual for there 'is considerable evidence that organizations often change through a sequence of small, frequent changes and inferences formed from experience with them' (Levitte and March 1988:334; Zarkin 2010). With the theoretical foundation set, the following section provides a historical context to opium in Turkey.

\section{Context: Opium in Turkey}

The opium poppy has been cultivated in the Anatolian region of Turkey for millennia (Murphy and Steele 1971). It was used for food, medicine and animal feed (Brundage and Mitchell 1977). Production and export, however, remained limited (Chambliss 1977) until 1805 when American merchants began exporting Turkish opium to China (Downs 1968; Spain 1975). While China was, at 
James Windle. (2013). 'A Very Gradual Suppression: A History of Turkish Opium Controls, 1933-1974'. European Journal of Criminology. Pre-print copy.

the time, the world's largest market for opium, as its importation had been prohibited in 1799 trade with China was illegal (Windle 2012). Turkish opium was also exported to Europe, North America and Persia (Evered 2011a).

In 1828 , the state monopolised production and distribution. While the monopoly intended to procure all opium for sale to private merchants (Poroy 1981), insufficient resources limited its power and:

The sale of opium to unauthorised merchants by local officials was prevalent ... Contraband was everywhere and smuggling proved to be insurmountable in spite of numerous edicts and repeated orders. The size of the contraband is estimated to be about one-third of legal purchases (Poroy 1981: 198).

The monopoly lasted 11 years. In 1839, it was dissolved due to lack resources, corruption, deficient administration (Schmidt 1998) and pressure from foreign pharmaceutical companies, who sought to procure opium directly from Turkish farmers (Poroy 1981).

In 1858, China legalised the importation of opium (Windle 2012). Turkey responded by gradually increasing its share of the newly licit market (Newman 1989) and by 1905 had become China's primary foreign source of smokable opium, alongside Iran (Musto 1987). Turkey also supplied opium to loosely regulated European pharmaceutical companies which manufactured and illicitly exported morphine to China and other states (Block 1989; Murn 1914).

By the 1930s, Turkey had become the world's primary source of opium to both the licit and quasilicit pharmaceutical industry; accounting for 226 metric tonnes of the total 390 metric tonne global supply of opium (Eisenlohr 1934; see Block 1989; Schmidt 1998). While opium was Turkey's fifth most important agricultural export, state control remained limited and diversion high (Eisenlohr 1934).

In 1925 and 1931, two international treaties were passed obliging states to regulate pharmaceutical industries to prevent the sale of opiates (i.e. morphine, heroin) for non-medical/scientific consumption 
James Windle. (2013). 'A Very Gradual Suppression: A History of Turkish Opium Controls, 1933-1974'. European Journal of Criminology. Pre-print copy.

(Bayer and Ghodse 1999). As European nations gradually strengthened controls, several pharmaceutical companies relocated to Turkey to circumvent regulations and continue manufacturing opiates for non-medical/scientific consumption (Block 1989; Eisenlohr 1934; Times 1931).

The League of Nations (cited in Times 1931: 13; see League of Nations 1936) reported in 1931 that 'no part of the [Turkish opiate] output ... is applied for bona-fide medical and scientific purposes'. Turkey was suspected of producing at least 14 metric tons of unsupervised heroin and morphine every month in three laboratories in Istanbul (Schmidt 1998). As the average ratio of opium to heroin is approximately 10:1 (Zerel et al. 2005) Turkey required at least 140 metric tonnes of opium to source just these three domestic laboratories. Furthermore, the majority of Turkish opium was smuggled to Europe where it was either transhipped towards China for consumption as prepared (smokable) opium (Schmidt 1998) or, manufactured into morphine or heroin in France and Italy. In 1928, for example, France imported from Turkey three times the total global medicinal requirement of opium (Block 1989; see Meyer and Parssinen 2002). Increased demand from foreign and domestic opiate manufacturers inflated Turkish opium production (Eisenlohr 1934) from already significant levels.

\section{The beginning of laissez faire control: 1933-1960s}

After ratifying the International Opium Convention in 1933, Turkey enacted its first domestic drug control legislation (Government of Turkey 1986; West 1992): the Limitations Law (No.2253) (Bulletin of Narcotics 1950). The Law mandated the Council of Ministers to annually determine the number of provinces permitted to extract opium gum from poppies or cultivate opium poppies for seeds; for which opium extraction was prohibited (Bulletin of Narcotics 1950). Substitute crops were encouraged in areas banned from production (League of Nations 1936), including the construction of sugar factories (League of Nations 1938). The Agricultural Bank was awarded a monopoly over the procurement and sale of all opium (Schmidt 1998).

Then, in 1938, Law No.3491 transferred monopoly powers to the newly established Toprak Mahsulleri Ofisi (TMO, Soil Products Office) (TMO-Alkasan 1989; see CND 1945). Control centred 
James Windle. (2013). 'A Very Gradual Suppression: A History of Turkish Opium Controls, 1933-1974'. European Journal of Criminology. Pre-print copy.

upon the opium declaration system: the Ministry of Agriculture annually calculated how much land would be required to yield a predetermined quantity and granted provinces permission to produce opium. Farmers in designated provinces informed their Muhtar (village leader) of their expected yield. Self-estimations were relayed to the Ministry of Agriculture and farmers were expected to adhere to them (Akçasu 1952; Murphy and Steele 1971; also League of Nations 1938). All residents of designated province were permitted to produce opium without a license and, were free to possess and store unlimited quantities of opium (see Akçasu 1952; Bulletin of Narcotics 1949; CND 1944, 1945, 1946, 1951, 1955, 1957). Monitoring was conducted by the Muhtar, who informed the TMO of any contravention (CINC 1972).

Regulatory and monitoring systems were ineffective (Akçasu 1952; Lamour and Lamberti 1974), and TMO prices 'neither repaid [farmers] for their troubles and outlay nor gave them the profit they were entitled to expect' (League of Nations 1938: 45 see Murphy and Steele 1971). ${ }^{2}$ As such, the majority of farmers continued to illicitly sell a significant percentage of their opium (Akçasu 1952; Lamour and Lamberti 1974).

Additionally, opium poppy cultivation was permitted for the harvesting of seeds in many provinces where opium production was prohibited (Bulletin of Narcotics 1950). Turkey conceded in 1968 that it was unable to administer effective controls over farmers in border areas (Greenfield and Nanby 1974; INCB 1969, 1971). This would suggest that the state was unable to prevent farmers from extracting opium from poppies officially grown for their seeds.

In general, rural population's only interaction with the state was with tax collectors and army conscription officers (Rustow 1967). As late as the early-1970s many opium farmers had 'rather distant relationships with the state' (Evered 2011b: 169). Therefore, due to the lack of control over rural areas and the laissez faire opium declaration system, drug control may have been little more than pretence.

During the 1940s state institutions had, however, 'became more effective and visible' in rural areas, this included tax collection and criminal justice institutions (Zürcher 1998: 216; Rustow 1967). Furthermore, by the late-1940s Turkey began administering a policy of increased agricultural 
James Windle. (2013). 'A Very Gradual Suppression: A History of Turkish Opium Controls, 1933-1974'. European Journal of Criminology. Pre-print copy.

production, and liberalization of trade policies, (Cecen et al. 1994) in which cheap credit was provided to farmers and the TMO paid artificially high prices for agricultural produce. The policy increased the number of tractors, hard-surfaced roads, arable land and the use of motor vehicles (Zürcher 1998: 235). Thus opening previously hard to reach rural areas to state institutions.

The 1933 Limitations Law also forced the closure of most opiate manufacturing laboratories (Block 1989; Times 1933). Nonetheless, raw opium continued to be exported to markets which prohibited its import, including: America, China, Egypt, Europe (Bulletin of Narcotics 1953), and Indochina (League of Nations 1930). Between 1931 and 1941, the League of Nations (1931) and UN (Bulletin of Narcotics 1953) declared Turkey one of the world's largest sources of illicit opium, alongside China and Iran.

In 1936, Turkey reported to the League of Nations (1938) that while significant tracts of land were cultivated with opium poppies the monopoly price had been deflated by decreased foreign demand for medicinal opium. Consequentially, as farmers could not afford to hire labourers, 75-80 percent of the crop remained un-harvested. ${ }^{3}$ As controls remained minimal, it is likely that $75-80$ percent was diverted, rather than wasted. This assumption is not unreasonable: in 1941 less than 15 percent of wheat production was surrendered to the TMO, even though all farmers were obliged to sell to the state monopoly, due to war time policy (Pamuk 1991).

While the Limitations Law had largely suppressed domestic opiate manufacturing by the mid1930s (CND 1945), Turkish opium continued to be converted to heroin in Italy (Murphy and Steele 1970; Rottenberg 1968). By 1952 the tightening of Italian pharmaceutical controls displaced much illicit manufacturing to France, which continued to procure Turkish opium (see McCoy 2003; Newsday 1974; Vaille and Bailleul 1953). Then, in 1955, Iran banned opium production. As Iran was a significant opium consumer, demand for the Turkish drug may have increased to fill the void created by the removal of Iranian opium; further inflating the level of Turkish diversion (Wishart 1974).

Heroin, made from Turkish opium, was smuggled to America in such quantities that, in 1958, the US Secretary of State requested the Turkish Prime Minister to prohibit opium. The Turkish Prime 
James Windle. (2013). 'A Very Gradual Suppression: A History of Turkish Opium Controls, 1933-1974'. European Journal of Criminology. Pre-print copy.

Ministers refusal marked the beginning of a tense period for Turkish-American relations (Uslu, 2003) and the escalation of external pressure for change.

In summary, until the 1960 s, control was limited to gradually restricting permissible production areas (see Table 1) to where the state possessed greatest authority and away from areas with easy export access (i.e. border areas). While the TMO declared the provincial restriction policy 'gradual and calculated', there is insufficient information on how bans were enforced. The repressive use of the military against Kurdish minorities in border provinces (Robins 1993; Zürcher 1998) may suggest the possibility of coercive suppression.

Table 1. Provinces permitted to produce opium

\begin{tabular}{l|l}
\hline Date & No. of provinces permitted to produce opium \\
\hline Pre-1933 & 62 (no limitation) \\
1940 & 42 \\
By late-1940s & 42 (banned in areas situated within 100km of national border) \\
1961 & 35 \\
1962 & 25 \\
1964 & 16 \\
1968 & 11 (banned in all border provinces) \\
1969 & 7
\end{tabular}

Source: Government of Turkey (1986); also Bulletin of Narcotics (1950); League of Nations (1938); INCB (1968).

\section{Improved (but still laissez faire) controls: 1960s}

In 1965 Turkey ratified the UN Single Convention: this represented an indication that it would cooperate further against illicit drug traffic. Turkey then began training and equipping specialist counter-narcotic police squads. In 1967, 1,000 police and gendarmes were posted in opium growing 
James Windle. (2013). 'A Very Gradual Suppression: A History of Turkish Opium Controls, 1933-1974'. European Journal of Criminology. Pre-print copy.

regions to try and prevent diversion. America lent their support by tracking opium merchants and, in 1968, loaned Turkey US\$3 million for the development of crop substitution (Urul 2003).

During the 1960 s, to prevent diversion, the TMO increased its prices by 66 percent, made it easier for farmers to deliver opium to monopoly agents, ensured all farmers were paid with cash (many farmers had previously been paid with food coupons), and publicised penalties for non-compliance (CINC 1972). Additionally, French and American interdiction of French heroin manufacturers and traffickers in the late-1960s/early-1970s (see GOA 1972, 1975; Times 1970, 1971, 1972; Wigg 1974) may have reduced demand for Turkish opium.

These measures, alongside the further contraction of provinces (see Table 1), did improve the amount surrendered to the monopoly (Turnbull 1972). This led the League of Nations Permanent Central Opium Board (PCOB) (1965: xxix) to note with 'approval' and 'satisfaction' that restrictions were a 'step in the right direction' (PCOB 1966: xx). The opium declaration system, however, remained deficient:

Since yields varied from year to year, the farmer tended to understate expected yields for he was liable for prosecution if he did not deliver to the [TMO ]... the total amount of gum he had reported in his declaration. In general, little effort was made to question farmer declarations or to verify actual yield at harvest time. Thus, this system allowed for considerable opportunity for underreporting yields (CINC 1972: A3)

One former opium farmer recalled how: 'No permission slips or licenses were required; we just planted as much as we wanted - and could harvest.' The primary limitation on opium production was the labour intensity of opium gum harvesting, rather than the state (Evered 2011b: 170). ${ }^{4}$ Enforcement institutions tended to be inefficient, under resourced and lacked training in narcotics control (Murphy and Steele 1971; Newsday 1971). While increased seizures by the mid-1960s (Robins 2007) were 
James Windle. (2013). 'A Very Gradual Suppression: A History of Turkish Opium Controls, 1933-1974'. European Journal of Criminology. Pre-print copy.

testament to improved surveillance of opium farmers (Murphy and Steele 1972), sanctions remained minimal and deterred few (Evered 2011b).

Furthermore, state controls over distribution were diluted by farmers being legally entitled to possess opium. This allowed farmers to store overproduced opium, which could be sold as and when (Murphy and Steele 1971). Additionally, provincial bans were limited to the less significant producers: a review of Turkish agriculture in the late-1940s failed to report opium production as important for any province outside of the Aegean, Mediterranean, Afyon, and lakes regions (Erinç and Tucdilek 1952). Throughout the 1960s, Afyon alone accounted for 80 percent of all opium produced in Turkey (Government of Turkey 1986). Provincial bans may, therefore, have had little impact on overall licit or illicit output.

In addition to poor controls the state provided little incentive for cooperation. The monopoly remained a 'sometimes problematic, distant, and lower-paying buyer', often paying as little as 20 percent less than black market merchants. Diverted opium was often collected directly from the farmgate, whereas the monopoly made farmers travel to market (Evered 2011b: 179).

While the innovations of the 1960s may have reduced the level of diversion, it remained high. In 1966, Iran complained to the Central Treaty Organisation (CENTO) that opium diverted from the Turkish monopoly supplied 25 percent of its black market (British Foreign Office 1966). America had also complained to CENTO in 1961 that 70 percent of all heroin consumed in America was sourced from French heroin laboratories, supplied by 'Middle Eastern', primarily Turkish, opium fields. While the Turkish delegate replied that controls were stringent, the accusation was not refuted (British Foreign Office 1961). By the mid-1960s, the American estimate had increased to 80 percent (Economist 1974; Musto 1987; Lamour and Lamberti 1974). America never validated the estimation (Epstein 1977; Evered 2011a) and it drew complaints from the Turkish (Government of Turkey 1986) and French governments (Epstein 1977). While 80 percent is likely an overestimate, Turkey was the predominant source of opium for heroin destined for America (McCoy 2003; Murphy and Steele 1971; Rottenberg 1968). 
James Windle. (2013). 'A Very Gradual Suppression: A History of Turkish Opium Controls, 1933-1974'. European Journal of Criminology. Pre-print copy.

During the mid/late-1960s, there was no agreement amongst American sources of the level of diversion. The Drug Enforcement Agency (1995) estimated that one-third of Turkish opium was diverted. The Bureau of Narcotics and Dangerous Drugs compared expected and actual yields to estimate two-third diversion (Holahan and Henningen 1972; see Epstein 1977). The Committee on International Narcotics Control (CINC) (1972, see Table 2) estimated that diversion decreased from 69.5 percent to 26 percent between 1967 and 1971. An American ambassador to Turkey reported to a journalist that 25 percent was diverted (Epstein 1977). The CINC was the only American organisation to confess to significant error margins in their estimate (CINC 1972).

While the two-third estimate is the one most often cited (West 1992), Robin (2007: fn14) suggests that it was 'bandied around' so much that it became 'conventional wisdom through repetition, without being established on any firm foundation.' This said, Newsday (1974) reporters conducted fieldwork in opium growing areas and interviewed farmers to conclude that two-thirds was likely. Other journalists, conversely, reported five (Munir 1970, cited in Robins 2007) and ten percent by the late1960s/early-1970s (Howe 1980).

Table 2. CINC diversion estimates

\begin{tabular}{l|ccccc}
\hline & 1967 & 1968 & 1969 & 1970 & 1971 \\
\hline Percentage diverted & 69.5 & 52.3 & 46.5 & 58 & 26 \\
In metric tonnes & 205 & 137 & 110 & 80 & 49
\end{tabular}

Source: adapted from CINC (1972).

Furthermore, the Turkish Government confessed to the International Narcotics Control Board (INCB) (1974: 13) that 'substantial quantities' of opium were entering the global illicit market, regardless of increased controls. The INCB (1971: 13) summarised the situation in the 1960s:

Frequent appearance in the illicit traffic of opium, or opium derivatives, known or presumed to have originated from Turkey has made this country a focus of 
James Windle. (2013). 'A Very Gradual Suppression: A History of Turkish Opium Controls, 1933-1974'. European Journal of Criminology. Pre-print copy.

international concern for a number of years. Counter-measures have not been lacking, yet the stream of such substances has persisted and has caused much disquiet ...

\section{Illicit production/diversion summary}

Reports to the League of Nations (1938) indicate diversion rates of between 75 and 80 percent in 1936. The 1936 estimate can be placed with American estimates provided in the mid/late-1960s to produce three diversion rate parameters, expressed in Figure 1: A high (80 percent), middle (66 percent), and low (25 percent). Fluctuations within these three parameters appear to follow the subsequent trend: Diversion appears high (80 percent) from at least 1936 (possibly peaking after the 1955 Iranian prohibition) to the 1960s when the imposition of more stringent controls make twothirds (66 percent) appear likely. By the early-1970s the low-parameter (25 percent) appears feasible, although diversion may have been as low as five percent (Windle 2011).

Figure 1. Turkey: Diverted opium (1931-1972)

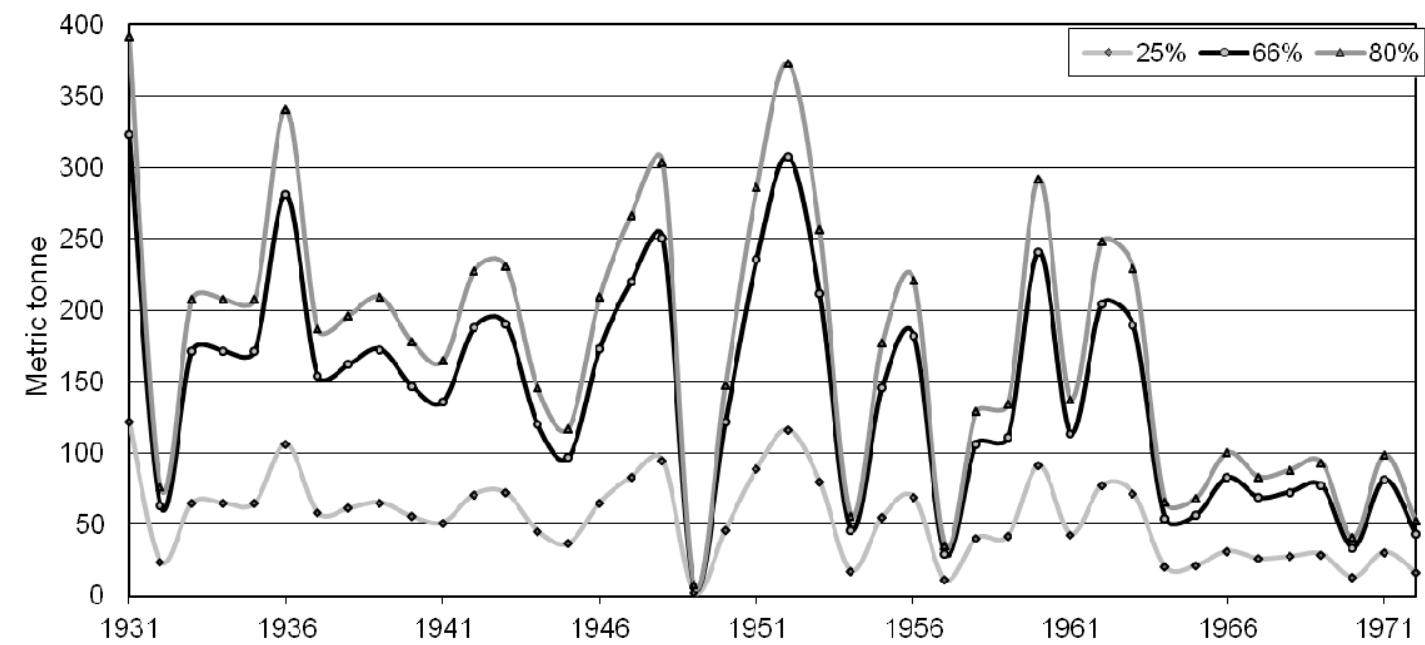

Sources: adapted from, Bulletin of Narcotics (1949, 1950); CINC (1972); Grey (1925); INCB (various years); League of Nations (1941, cited in Block, 1989); PCOB (various years).

These observations have some insight for our understanding of the geographical displacement of illicit drug crops. It is commonly believed that the cessation of production in Turkey in 1972 
James Windle. (2013). 'A Very Gradual Suppression: A History of Turkish Opium Controls, 1933-1974'. European Journal of Criminology. Pre-print copy.

displaced production to Afghanistan (Costa 2009; Paoli et al. 2009), Pakistan (Haq 1996; Murphy 1983; Paoli et al. 2009) and/or, Laos and Viet Nam (Fazey 2005).

If, however, opium production had been gradually declining from the mid-1960s then it is possible that traffickers had already begun looking for new sources of opium. That is, displacement may have occurred before 1971. If the lower parameter ( 25 percent) is relevant in 1971, then the removal of Turkish opium would have had little impact on the global market. ${ }^{5}$ Between 1970 and 1972 Turkey produced an average of 62 metric tonnes; Afghanistan produced an average of 106 metric tonnes and Pakistan produced an average of 205 metric tonnes (Holahan and Henningsen 1972; NNICC 1973). The impact would have been even less significant if the five percent estimate can be validated.

This would suggest that the Turkish opium ban had either minimal global impact or displacement occurred much earlier, depending on the level of diversion. Of course multiple other factors may have influenced displacement, including inexact information on diversion and foreign production, and the existence of stores of Turkish opium creating a lag in supply. What this does suggest, however, is that analysis of displacement must be rigorously evaluated and not simply assumed (see Windle and Farrell 2012) as appears to have been the case in the early-1970s.

\section{The 1971 opium ban and its partial repeal in 1974}

In 1971, Turkey passed the Opium Licensing and Control Law. The Law introduced the licensing of all opium farmers, barred farmers with a criminal record from obtaining a license (CINC 1972), and criminalised the possession of unlicensed opium (GOA 1972). Then, later that year, the civilian government was overthrown in a military coup (Zürcher 1998). The new regime banned all opium production and cultivation, under Decree No.7/2654 (Kamminga 2007; Robins 2007).

The ban was partly motivated by increasingly aggressive pressure placed on Turkey by America. Since the late-1950s America had been requesting that Turkey prohibit all opium. The negotiations had become progressively more coercive throughout the 1960s. All American consulates were told to bring up the 'opium issue' at every available opportunity, Turkey was informed that not prohibiting opium would harm American-Turkish relations and, there were threats of economic sanction and 
James Windle. (2013). 'A Very Gradual Suppression: A History of Turkish Opium Controls, 1933-1974'. European Journal of Criminology. Pre-print copy.

withdrawal of aid. Additional motivating factors included the militaries belief that leftist insurgents were profiting from the illicit opiate market and concerns that being a source of illicit opium was tarnishing Turkey's reputation as a modern state (Uslu, 2003).

The ban was funded by US\$35 million in American aid, to compensate farmers and the state for loss of earnings, and develop crop substitution programmes (Spain 1975; see Brundage and Mitchell 1977; INCB 1973; US Information Service 1971). A further US\$300,000 was agreed to procure the final opium crop and US $\$ 400,000$ to pay the wages of American advisors to crop substitution projects (GOA 1975).

Newsday (1974) reported that there were no violent oppositions to the ban (although many villagers hid poppy seeds in anticipation of repeal). An American Senator, conversely, reported to Hatch (1984: 2) that 'the Turkish Army played a key role in its enforcement', indicating that enforcement included some coercion. Furthermore, many provinces were already under martial law (Sayari and Hoffman 1991).

Not only did opium represented a significant percentage of many farmers annual income, but the ban limited access to traditionally consumed opium poppy by-products such as oil, animal-feed and fuel (Brundage and Mitchell 1977; Evered 2011a). While all farmers were compensated for loss of earnings (some even profited) (Evered 2011b), 'most complained' about delayed or insufficient payments (Evered 2011a: 309; see Greenfield and Nanby 1974; Spain 1975). Furthermore, crop substitution failed to deliver alternative incomes. The unstable military regime was unable to effectively administer crop substitution projects (Brundage and Mitchell 1977; GOA 1975). As baseline agricultural research was lacking, many new crops were unsuited to local soil and weather conditions (Government of Turkey 1986; also Time 1974; West 1992), and the poor transport infrastructure (Newsday 1974). These inefficiencies meant that substitute crops were often six to ten times less profitable than opium (Evered 2011a). ${ }^{6}$ In short, the crop substitution strategy was poorly funded and designed, and as opium was banned before farmers had access to alternative incomes, it was poorly sequenced (Chouvy 2009). The ban impoverished many farmers, forcing them to migrate 
James Windle. (2013). 'A Very Gradual Suppression: A History of Turkish Opium Controls, 1933-1974'. European Journal of Criminology. Pre-print copy.

to urban areas (Klose 1981). This created 'a potentially dangerous social resentment ... among the people affected by the ban' (Government of Turkey 1986: 9).

In addition to impoverishing farmers, the ban - which cost Turkey an estimated US\$400 million (West 1992) - fuelled perceptions of national subservience to American interests (Evered 2011a; Robins 2007; Zürcher 1998); making the repeal of prohibition an issue of national pride (Fyjis-Walker 1974; Warren-Gash 1974; see Sarell 1970). There was, in short, extensive popular and political opposition to the ban (Brundage and Mitchell 1977; Fyjis-Walker 1974; Warren-Gash 1974). Consequently, in 1974, the new government - partially elected by a rural electorate (British Foreign and Commonwealth Office 1972) on a pro-opium platform (Robins 2007) - began cultivating poppy seeds in state farms to prevent them from going stale (British Foreign and Commonwealth Office 1974; Warren-Gash 1974).

\section{The ban on unregulated opium}

The ban on cultivation was lifted in seven provinces by Decree No.7522, in July 1974. As the Decree prohibited the extraction of opium, the ban on production remained. A monopoly system was established whereby farmers were licensed to produce poppy straw to be manufactured into morphine

(see Government of Turkey 1986; Warren-Gash 1975; UNFDAC 1975; also Decree No.7/8522; Decree No.7/9204). ${ }^{7}$ The policy was founded upon reducing opportunities for diversion from regulated production by hardening targets, increasing formal and informal surveillance, assisting compliance through fair procurement practices and increasing the risk of non-compliance (Windle under consideration; also Government of Turkey 1988; Mansfield 2001).

The policy has been successful. Since 1974, America (DEA 1995; NNICC 1981, 1988; US State Department 1996-2007), Britain (Mansfield 2001), Interpol (1988) and the UN (UNODCCP 2000; INCB 1975, 1977, 1979, 1980, 1982) have reported how controls have limited diversion to practically nil (also Jensema and Archer 2005). While small amounts of opium were illicitly produced in the early-1980s (NNICC 1980, 1981) the practice has remained minimal.

As importantly, retired opium farmers interviewed by Evered (2011a: 310) recalled how the poppy straw method was profitable: 'People planted again, got money, got married, got land, and got tractors. 
James Windle. (2013). 'A Very Gradual Suppression: A History of Turkish Opium Controls, 1933-1974'. European Journal of Criminology. Pre-print copy.

We were happy again'. Part of the reason was that as poppy straw farming is less labour intensive than harvesting opium gum, farmers could cultivate more poppies (depending on the permission of the state) or other crops (Evered 2011b,c).

\section{Discussion}

While post-1971 Turkish opium control policies have received significant attention there has been limited prior analysis of controls administered between 1933 and 1971. The period between 1933 and the early-1960s was characterised by laissez faire controls centred upon the gradual restriction of permissible areas to where the state possessed greatest authority and, a flawed opium declaration system dependent upon the honesty of farmers. That farmer's would not produce more than they declared to the state, or extract opium from poppies grown for their seeds, was naive. It was equally naive to allow all residents of an area to produce opium without a license and, be free to possess and store unlimited quantities of opium.

Coupled with the lack of state presence before the 1940s, Turkey lacked any real mechanism to monitor farmers or enforce compliance. Furthermore, ineffective procurement practices provided farmers with little reward for compliance. Together, these laissez faire controls and poor procurement practices provided significant and profitably opportunities for diversion. This said, the repressive use of the military against Kurdish minorities in border provinces may suggest the possibility of coercive suppression in some Kurdish opium producing areas. This is an area which requires further investigation.

Turkish controls improved as the state extended its authority into the countryside during the 1940s. Then, during the 1960s, the TMO improved surveillance and procurement practices; learning from earlier failures to limit diversion. The monopoly, however, remained ineffective, largely due to an inability to compete with black market traders who paid more and procured at the farm-gate. Sanctions provided minimal risk and thus deterred few. Possibly the most important limitation remained the flawed opium declaration system. That is, while controls improved during the 1960s they remained centred upon a laissez faire model of control. 
James Windle. (2013). 'A Very Gradual Suppression: A History of Turkish Opium Controls, 1933-1974'. European Journal of Criminology. Pre-print copy.

The gradual restriction of opium production areas and increases in regulatory controls before 1971 was of limited success. The 1971 opium ban was equally limited. Turkish hastiness to prevent opium production meant that crop substitution programmes were ill thought-out failures. Subsequently, the ban produced major unintended consequences for rural communities and political stability. Success was finally achieved in 1974 with a policy founded upon reducing opportunities for diversion by hardening targets, increasing formal and informal surveillance, assisting compliance through fair procurement practices, and increasing the risk of non-compliance.

The 1974 intervention can be seen as the latter end of a process of gradual improvement. One where successive Turkish state institutions and foreign sponsors (i.e. League of Nations/UN) formally and informally acquired, interpreted and analysed successes and, more importantly, failures. This said, the policy may have developed without any learning from past successes and failures: external pressure, and the existence of a more competitive producer (Afghanistan), may have forced the change regardless of earlier experiences. Drawing on past experiences may well, however, have been 'necessary' to produce such an effective policy (Zarkin, 2010: 172).

Organisational learning was motivated by increasing external and internal pressure to prevent diversion. By the time that Turkey prohibited the extraction of opium gum a formal and informal body of knowledge concerning 'what works', and more importantly 'what does not work', had been amassed: The end result being a highly effective control policy with few of its predecessor's weaknesses. That is, state organisations had gradually learnt that laissez faire controls, and poor procurement practices, presented farmers with significant opportunities for diversion.

\section{Note}

'Diversion' is the rather innocuous-sounding technical term by which drug policy refers to the theft of opium at any point along regulated production and distribution lines.

${ }^{2}$ As the TMO often stored opium for up to six weeks the moisture content was reduced, which reduced the weight and hence price (Murphy and Steele 1971). 
James Windle. (2013). 'A Very Gradual Suppression: A History of Turkish Opium Controls, 1933-1974'. European Journal of Criminology. Pre-print copy.

${ }^{3}$ This may not be unreasonable if compared to similar diversion rates recorded at the time in Iran, which possessed a more sophisticate control mechanism (Windle 2011).

${ }^{4}$ Opium is a labour intensive crop. Harvesting alone may necessitate an entire family (or village), plus labourers, working uninterrupted for several weeks (see Mansfield 2001; Westermeyer 2004).

${ }^{5}$ The Turkish ban did have a significant impact on the American and Iranian markets: both witnessed heroin droughts (see Agar and Reisinger 2002; GOA 1975, 1979; McCoy 2003; Reuter 1985). The impact on other national markets is less clear.

${ }^{6}$ Pakistan and Thailand later administered more effective programmes. These were more widerranging in terms of socio-economic developmental objectives and sequenced bans until after farmers had access to alternative incomes (see Mansfield 1999; Renard 2001)

${ }^{7}$ The production of opium from poppy straw is significantly different from that of incising poppy pods. The poppy plant is cultivated in the same manner as elsewhere; however, at harvest the farmer is prohibited from incising the poppy pods to collect the opium gum within. Instead, farmers cut and crush the poppies. The crushed poppies represent the poppy straw which is then sold to the state. The morphine is extracted using expensive technology that is not generally available (Mansfield 2001; see Bayer 1983). As long as farmers are monitored during harvest the poppy straw process can make diversion more difficult (Bayer 1983; Mansfield 2001; West 1992).

\section{References}

Agar M and Reisinger H.S (2002) A Tale of Two Policies The French Connection, Methadone, and Heroin Epidemics. Culture, Medicine and Psychiatry 26, 371-396.

Akçasu A (1952) The Changes Experienced by the Narcotics Monopoly in Turkey. Bulletin of Narcotics 3(1), 6-9.

Bayer I (1983) The Monitoring of Trade in and Control of Psychotropic Substances to Guard Against their Diversion. Bulletin on Narcotics 4, 3-13.

Bayer I and Ghodse H (1999) Evolution of International Drug Control, 1945-1995. Bulletin of Narcotics 51(1/2), 1-19. 
James Windle. (2013). 'A Very Gradual Suppression: A History of Turkish Opium Controls, 1933-1974'. European Journal of Criminology. Pre-print copy.

Block A.A (1989) European Drug Traffic and Traffickers between the Wars: The Policy of

Suppression and Its Consequences. Journal of Social History 23(2), 315-337.

British Foreign Office (1961) British Embassy, Tehran to Foreign Office. June 22, 1961. British

National Archives, Kew London: FO 371/157503.

British Foreign Office (1966) CENTO. Report of the Third Session of the Working Party on Narcotics

Control. June 1st 1966. British National Archives, Kew London: 371/186536

British Foreign and Commonwealth Office (1972) Essential Facts. British National Archives, Kew London: FCO 9/1841.

British Foreign and Commonwealth Office (1974) ECOSOC: Narcotic Drugs, Agenda Item No. 9 , 56th Session of the United Nations Economic and Social Council: Provisional Agenda and Brief. British National Archives, Kew London: FCO 61/1227.

Brundage W and Mitchell W (1977) Towards an Understanding of Opium Poppy Production in Turkey. Journal of Asian and African Studies 12(1), 259-168.

Bulletin of Narcotics (1949) Opium Production Throughout the World. Bulletin of Narcotics 1(1), 638.

Bulletin of Narcotics (1950) The Cultivation of the Opium Poppy in Turkey. Bulletin of Narcotics 2(1), 13-25.

Bulletin of Narcotics (1953) Illicit Traffic in Opium. Bulletin of Narcotics 5(3), 24-29.

Cecen A.A, Dogruel S and Dogruel F (1994) Economic Growth and Structural Change in Turkey 1960-88. International Journal of Middle East Studies 26(1), 37-56.

Chambliss W.J (1977) Markets, Profits, Labour and Smack. Contemporary Crises 1, 53-76.

Chouvy P (2009) Opium: Uncovering the Politics of the Poppy. London: I.B.Taurus.

CINC (Committee on International Narcotics Control) (1972) World Opium Survey 1972.

Washington: US Government Printing Office.

Costa M (2008) Making Drug Control "Fit for Purpose": Building on the UNGASS Decade. Commission on Narcotic Drugs: E/CN.7/2008/CRP.17 
James Windle. (2013). 'A Very Gradual Suppression: A History of Turkish Opium Controls, 1933-1974'. European Journal of Criminology. Pre-print copy.

CND (Commission on Narcotic Drugs) (1944-1957) Summary of Annual Reports of Governments.

New York: CND.

DEA (Drug Enforcement Agency) (1995) Drug Trafficking in Southwest Asia and the Central Asian

States: Drug Intelligence Report. DEA-95055.

Decree No.7/8522 (1974) Decree to Authorize Opium Poppy Cultivation in the Seven Provinces

During 1974-1975. Retrieved January 18, 2009, from http://www.unodc.org/doc/enl/1974-46.pdf

Decree No.7/9204 (1975) In Official Gazette, No.15120, 16 January. Retrieved January 18, 2009, from http://www.unodcorg/doc/enl/1975-9.pdf

Downs J.M (1968) American Merchants and the China Opium Trade, 1800-1840.The Business History Review 42(4), 418-442.

Economist (1974) Poppy Power. The Economist, 13 July.

Erinç S and Tuncdilek N (1952) The Agricultural Regions of Turkey. Geographical Review 42(2), 179-203.

Eisenlohr L.E.S (1934) International Narcotics Control. London: George Allen and Unwin.

Epstein E (1977) Agency of Fear: Opiates and Political Power in America. New York: Putnam's and Son.

Evered K.T (2011a) "Poppies are Democracy!': A Critical Geopolitics of Opium Eradication and Reintroduction in Turkey'. Geographical Review 101(3), 299-31

Evered K.T (2011b) Traditional Ecologies of the Opium Poppy and Oral History in Rural Turkey. Geographical Review 101(2), 164-182

Evered K.T (2011c) The Opium Poppy in Turkey: Alternative Perspectives on a Controversial Crop. Focus on Geography 54(1), 1-10.

Fazey C (2005) Where Have all the Flowers Gone? Gone to Opium Everyone. When Will They Ever Learn, When Will They Ever Learn? International Journal of Drug Policy 16(2), 104-107. Fyjis-Walker (1974) US/Turkish Relations. Letter to A.C. Goodison (FCO). British National Archives, Kew London: FCO 9/2129. 
James Windle. (2013). 'A Very Gradual Suppression: A History of Turkish Opium Controls, 1933-1974'. European Journal of Criminology. Pre-print copy.

Grey W.A (1925) The Opium Problem. Annals of the American Academy of Political and Social Science 122, 148-159.

Greenfield H and Nanby M.C (1974) Report and Recommendations of the United Nations Mission to Turkey, 26 August - 10 September 1974. British National Archives, Kew London: FCO 9/2129. GOA (Government Accounting Office) (1972) Efforts to Prevent Heroin from Illicitly Reaching the United States. B-164031(2). Washington: GOA.

GOA (Government Accounting Office) (1975) If The United States Is To Develop An Effective International Narcotics Control Program, Much More Must Be Done. Report to Congress. E175425. Washington: GOA.

Government of Turkey (1986) Facts on Turkish Poppy. Ankara: Directorate General of Press and Information.

Government of Turkey (1988) Turkey's Narcotics Control in Turkey. Ankara: Ministry of Health and Social Assistance General Directorate of Pharmaceuticals.

Hatch O (1984) Stop Imported Heroin. New York Times, 5 May.

Haq I (1996) Pak-Afgan Drug Trade in Historical Perspective. Asian Survey 36(10), 945-963.

Holahan J and Henningsen P (1972) The Economics of Heroin. In The Ford Foundation (ed.) Dealing with Heroin. London: Praeger Publishers.

Howe M (1980) Turkish Farmers Turn Bitterly from Opium Poppy. New York Times, 28 November. INCB (International Narcotics Control Board) (1968-1974) Report of the INCB UN: New York.

\section{$\mathrm{E} / \mathrm{INCB} /$}

Interpol (1988) The Quest Review. Vienna: Interpol.

Jensema E and Archer G (2005) Licensed Opium Cultivation and Production in the Main Producing Countries. In Senlis Council (eds.) Feasibility Study on Opium Licensing in Afghanistan for the production of morphine and other essential medicines. The Senlis Council.

Kamminga J (2007) The Political History of Turkey's Opium Licensing System for the Production of Medicines: Lessons for Afghanistan. Senlis Council. Retrieved October 12, 2008, from www.icosgroup.net/.../Political_History_Poppy_Licensing_Turkey_May_2006.pdf 
James Windle. (2013). 'A Very Gradual Suppression: A History of Turkish Opium Controls, 1933-1974'. European Journal of Criminology. Pre-print copy.

Kenney M (2007) From Pablo to Osama: Trafficking and Terrorist Networks, Government Bureaucracies, and Competitive Advantage. Pennsylvania: Penn State University Press.

Kenney M (2009) Organizational Learning and Islamic Militancy, Washington: National Institute of Justice, U.S. Department of Justice.

Klose K (1981) Accused Turk Looked for Exit From Poverty. The Washington Post, 22 May.

Lamour K and Lamberti M.R (1974) The Second Opium War. (Translated by Ross P and Ross B). London: Allen Lane.

League of Nations (1930) Commission of Enquiry into the Control of Opium-Smoking in the Far East: Report to the Council: Detailed Memoranda on Each Territory Visited by the Commission. C.635.M.254.1930.

League of Nations (1931) Commission of Inquiry into the Control of Opium-Smoking in the Far East. C.635.M.254.1930.

League of Nations (1936) Nineteenth Assembly: Seventh Committee. Traffic in Opium and Other Dangerous Drugs. A.VII/5.1936.

League of Nations (1938) Advisory Committee on Traffic in Opium: Report to the Council Concerning the Preparatory Work for a Conference to Consider the Possibility of Limiting and Controlling the Cultivation of the Opium Poppy and the Production of Raw Opium and Controlling Other Raw Material for the Manufacture of Opium Alkaloids. XI.1.

Levitt B and March JG (1988) Organizational Learning. Annual Review of Sociology 14, 319-340. Mansfield D (1999) Alternative Development: The Modern Thrust of Supply-Side Policy. Bulletin of Narcotics 51(1/2), 19-45.

Mansfield D (2001) An Analyses of Licit Poppy Cultivation: India and Turkey. Retrieved October 12, 2008, from http://www.davidmansfield.org/policy_advice.php

McCoy A (2003) The Politics of Heroin: CIA Complicity in the Global Drug Trade. Chicago: Lawrence Hill Books.

Meyer K and Parssinen T (2002) Webs of Smoke: Smugglers, Warlords, Spies, and the History of the International Drug Trade. Oxford: Rowman and Littlefield. 
James Windle. (2013). 'A Very Gradual Suppression: A History of Turkish Opium Controls, 1933-1974'. European Journal of Criminology. Pre-print copy.

Murn G.S (1914) The Morphia Traffic. 17 March 1914. British National Archives, Kew London: FO $228 / 2458$.

Murphy J (1983) Implementation of International Narcotics Control: The Struggle Against Opium Cultivation in Pakistan. Boston College International and Comparative Law Review 6(1), 199-247.

Murphy M and Steele R (1971) The World Heroin Problem. Washington: US Government Printing Office.

Musto D (1987) The American Disease: Origins of Narcotics Control. Oxford: Oxford University Press.

Newman R.K (1989) India and the Anglo-Chinese Opium Agreements, 1907-14. Modern Asian Studies 23(3), 525-560.

Newsday (1974) The Heroin Trail. London: Souvenir Press.

NNICC (National Narcotics Intelligence Consumers Committee) (1973-1991) The Supply of Drugs to the US Illicit Market. Washington: US Government Printing Office.

Pamuk S (1991) War, State Economic Policies and Resistance by Agricultural Producers in Turkey, 1939-1945. In Waterbury J and Kazemi F (eds.) Peasant Politics in the Modern Middle East. Florida: University Presses of Florida.

Paoli L, Greenfield V.A and Reuter P (2009) The World Heroin Market: Can Supply be Cut? Oxford: Oxford University Press.

PCOB (Permanent Central Opium Board) (Various years) Report to the Economic and Social Council on the Work of the Board. Geneva: United Nations. E/OB

Poroy I.I (1981) Expansion of Opium Production in Turkey and the State Monopoly of 1828-1839. International Journal of Middle East Studies 13, 191-211.

Renard R (2001) Opium Reduction in Thailand 1970-2000: A Thirty Year Journey. Chiang Mai: Silkworm Books.

Reuter P (1985) Eternal Hope: America's Quest for Narcotics Control. The Public Interest 79, 79-95. Robins P (1993) The Overlord State: Turkish Policy and the Kurdish Issue. International Affairs 69(4), 657-676. 
James Windle. (2013). 'A Very Gradual Suppression: A History of Turkish Opium Controls, 1933-1974'. European Journal of Criminology. Pre-print copy.

Robins P (2007) The Opium Crisis and the Iraq War: Historical Parallels in Turkey-US Relations. Mediterranean Politics 12(1), 17-38

Rottenberg S (1968) The Clandestine Distribution of Heroin, Its Discovery and Suppression. The Journal of Political Economy 76(1), 78-90.

Rustow D.A (1967) Politics and Development Policy. In Shorter F.C (ed.) Four Studies on the Economic Development of Turkey. London: Frank Cass.

Sarell R (1970) Turkey: Annual Review for 1970. 31st December 1970. British National Archives, Kew London: FCO 9/1466.

Sayari S and Hoffman B (1991) Urbanization and Insurgency: The Turkish Case, 1976-1980. California: RAND.

Schmidt J (1998) From Anatolia to Indonesia: Opium trade and the Dutch community in Izmir, 18201940. Leiden: Nederlands Instituute voor het Nabijie Oosten.

Schulz M (2005) Organizational Learning. In Baum J.A (ed.) The Blackwell Companion to Organizations. Oxford: Wiley.

Spain J.W (1975) The United States, Turkey and the Poppy. The Middle East Journal 29(3), 295-309. Time (1974) Turkey: Opium's Lethal Return. Time, 15 July.

Times (1931) The Trade in Opium. The Times, 27 May.

Times (1933) Drug Barons of Europe. The Times, 21 March.

Times (1970) Factories for Heroin Found. The Times, 24 July.

Times (1971) Huge Heroin Haul by French Police. The Times, 10 October.

Times (1972) Heroin Factory Seized by Police in Marseille. The Times, 7 March.

TMO-Alkasan (1989) TMO-Alkasan Turkish Opiates Board. Ankara: TMO.

Turnbull J.H (1972) Opium Narcotics: A World Survey of the Illicit Traffic. The Royal Military College of Science Department of Chemistry and Metallurgy: Technical Report AC/R/5.

UNFDAC (UN Fund for Drug Abuse Control) (1975) The Cultivation of Opium Poppy in Turkey. MNAR/8/1975 GE.75-8207. 
James Windle. (2013). 'A Very Gradual Suppression: A History of Turkish Opium Controls, 1933-1974'. European Journal of Criminology. Pre-print copy.

UNODCCP (UN Office for Drug Control and Crime Prevention) (2000) World Drug Report. Oxford:

Oxford University Press.

US Information Service (1971) Stepping up International Action Against Drug Abuse. American

Embassy: London. British National Archives, Kew London: FCO 15/1392.

US State Department (1995-2010) International Narcotics Control Strategy Report. Washington: US State Department.

Uslu, N (2003) The Turkish-American Relationship Between 1947 and 2003: The History of a Distinctive Alliance. New York: Nova.

Vaille C and Bailleul E (1953) Clandestine Heroin Laboratories. Bulletin of Narcotics, 4, 1-6.

Warren-Gash (1974) To Georgina Wright (FCO). 19th March, 1974. British National Archives, Kew London: FCO 9/2129.

Warren-Gash (1975) To C.S. Wright (FCO). Turkish Opium Poppy Cultivation. 9 September 1975.

British National Archives, Kew London: FCO 61/1369.

West C.S (1992) Turkey and India. In McDonald S and Zagarid B (eds.) International Handbook on Drug Control. Westport: Greenwood Press.

Westermeyer J (2004) Opium and the People of Laos. In Steinberg, M.K, Hobbs J.J. and Mathewson K (eds.) Dangerous Harvest: Drug Plants and the Transformation of Indigenous Landscapes. Oxford: Oxford University Press.

Wigg R (1974) Ringleader of French Heroin Smugglers Jailed for 18 Years. The Times, 12 July. Windle J (2011) Poppies for Medicine in Afghanistan: Historical Lessons from India and Turkey. Journal of Asian and African Studies 46(6), 663-677.

Windle J (2012) Insights for Contemporary Drug Policy: A Historical Account of Opium Control in India and Pakistan. Asian Journal of Criminology 7(1), 55-74.

Windle J (Under consideration) Turkish Opium Controls as Situational Crime Prevention. Security Journal. 
James Windle. (2013). 'A Very Gradual Suppression: A History of Turkish Opium Controls, 1933-1974'. European Journal of Criminology. Pre-print copy.

Windle J and Farrell G (2012) Popping the Balloon Effect: Assessing Drug Law Enforcement in Terms of Displacement, Diffusion and the Containment Hypothesis. Substance Use and Misuse, 47(8/9), 868-876.

Wishart D (1974) The Opium Poppy: The Forbidden Crop. Journal of Geography 73(1), 14-25.

Zarkin M.J (2010) The FCC and the Politics of Cable TV Regulation, 1952-1980: Organizational Learning and Policy Development. Amherst: Cambria Press.

Zerel U, Ahrens B and Gerz P (2005) Documentation of a Heroin Manufacturing Process in Afghanistan. Bulletin of Narcotics 61(1/2), 11-33.

Zürcher E (1998) Turkey: A Modern History. London: I.B. Tauris and Co. 